\title{
Proses Seeding dan Aklimatisasi pada Anaerobic Trickling Reactor
}

\section{WAYAN WINDU ADI SEMARTA ${ }^{1}$, ETIH HARTATI ${ }^{1}$, SALAFUDIN ${ }^{2}$}

\author{
1. Jurusan Teknik Lingkungan, Fakultas Teknik Sipil dan \\ Perencanaan, Institut Teknologi Nasional Bandung \\ 2. Jurusan Teknik Kimia, Fakultas Teknologi Industri, \\ Institut Teknologi Nasional Bandung \\ Email : winduadi064@gmail.com
}

\begin{abstract}
ABSTRAK
Pertumbuhan biomassa terlekat ditentukan oleh proses seeding dan aklimatisasi. Tujuan penelitian ini yaitu mengetahui proses seeding dan aklimatisasi pada anaerobic trickling reactor. Metoda penelitian yang digunakan meliputi persiapan reaktor hidrolisis dan 3 buah anaerobic trickling reactor dengan media yang berbeda, serta persiapan bahan meliputi inokulum dan substrat. Parameter yang diukur yaitu densitas, kadar air dan volatil, C-Organik, NTK, pH, temperatur, TAV, COD, dan alkalinitas mengacu pada SNI dan standard methods. Hasil penelitian ini yaitu saat proses seeding, nilai $\mathrm{pH} 6,87 \mathrm{hing}$ ga $\mathrm{pH} 7,52$, temperatur $27^{\circ} \mathrm{Chingga} 28^{\circ} \mathrm{C}$, dan ketiga media mengalami pertambahan berat rata-rata sebesar0,5421 gram/media (bioball rambutan)(12,93\%), 0,7158gram/media (bioball bola)(11,47\%), dan0,0449 gram/media(media straws)(13,95\%). Steadystate aklimatisasi terjadi pada hari ke-14 hingga hari ke-20 yang ditandai dengan penurunan konsentrasi COD yang konstan. Selama seeding dan aklimatisasi terbentuk biogas. Kesimpulan penelitian ini yaitu proses seeding dan aklimatisasi ditandai dengan terbentuknya lapisan biofilm dan adanya penurunan konsentrasi COD substrat.
\end{abstract}

Kata kunci: Anaerob, Seeding dan Aklimatisasi, Anaerobic Trickling Reactor

\begin{abstract}
Attached biomass growth is determined by seeding and acclimatization process. The purpose of this research is to know the seeding and acclimation process in anaerobic trickling reactor. The research method used includes the preparation of the tool that is hydrolysis reactor and 3 pieces of anaerobic trickling reactor with differentmedia, as well as the preparation of materials including inoculum and substrate. Parameters measured were density, water content and volatile, C-Organic, NTK, pH, temperature, TAV, COD, and alkalinity refer to SNI and standard methods. The result of this research is when seeding process, $\mathrm{pH}$ value $6,87 \mathrm{to} \mathrm{pH} 7,52$, temperature $27 \mathrm{C}^{\circ} \mathrm{until} 28^{\circ} \mathrm{C}$, and third media have average weight gain of 0,5421 gram/medium (rambutan bioball) (12,93\%), 0,7158 grams/medium (spherical bioball) (11,47\%), and 0,0449 gram/medium (media straws) (13,95\%). Steady state acclimatization occurs on the 14th day until the 20th day marked by a constantdecrease in COD concentrations. During seeding andacclimatization formed biogas. The conclusion of this research is the seeding and acclimatization process is characterized by the formation of biofilm layer and the decrease of COD concentration.
\end{abstract}

Keywords: Anaerobes, Seeding and Acclimatization, Anaerobic Trickling Reactor 


\section{PENDAHULUAN}

Proses anaerob diawali dengan tahap hidrolisis yaitu proses degradasi senyawa organik kompleks seperti karbohidrat, protein dan lemak yang kemudian di hidrolisis menjadi senyawa organik sederhana (glukosa, asam amino, dan asam lemak) (Indriyati, 2011). Setelah itu senyawa tersebut melalui proses asidogenesis berubah menjadi asam volatil yaitu propionat, butirat lalu berubah menjadi asetat, $\mathrm{H}_{2}$ dan $\mathrm{CO}_{2}$ melalui proses asetogenesis, kemudian melalui proses metanogenesis dirubah menjadi $\mathrm{CH}_{4}$ (metan) dan $\mathrm{CO}_{2}$ (karbon dioksida) (Indriyati, 2011). Salah satu reaktor yang dapat mengolah limbah organik secara anaerob yaitu reaktor dengan pertumbuhan biomassa terlekat (Indriyati, 2011). Pengolahan limbah organik secara anaerob dapat menghasilkan biogas yang berrmanfaat sebagai sumber energi alternatif pengganti bahan bakar fosil (Hermawan, dkk., 2007). Pertumbuhan biomassa terlekat sangat ditentukan oleh proses seeding dan aklimatisasi (Indriyati, 2011). Pertumbuhan biomassa terlekat yaitu mikroorganisme tumbuh dan berkembang biak diatas media pendukung dengan membentuk lapisan biofilm (Indriyati, 2011).

Reaktor yang digunakan dalam penelitian ini yaitu satu buah reaktor hidrolisis dan tiga buah anaerobic trickling reactor. Reaktor hidrolisis digunakan sebagai tempat pembuatan substrat cairan sampah organik. Anaerobic trickling reactor mengolah limbah organik secara anaerob dengan pertumbuhan biomassa terlekat. Media yang digunakan pada anaerobic trickling reactor 1, 2, dan 3 berturut-turut yaitu bioball rambutan, bioball bola, dan sedotan (straws). Tujuan proses seeding yaitu untuk menumbuhkan dan mengembangkan mikroorganisme anaerob yang akan digunakan untuk penelitian. Sedangkan aklimatisasi dilakukan untuk mengkondisikan mikroorganisme agar mampu hidup dan menyesuaikan diri dengan kondisi lingkungan yang baru (Andary, dkk., 2010) dalam (Ananda, 2016). Penelitian ini dilakukan untuk mengetahui proses seeding dan aklimatisasi pada anaerobic trickling reactor sampai terjadi steady state.

\section{METODOLOGI}

\subsection{Alat}

Alat yang digunakan dalam penelitian ini berupa 2 (dua) buah reaktor yaitu reaktor hidrolisis sebanyak 1 buah dan anaerobic trickling reactor sebanyak 3 buah. Reaktor hidrolisis terbuat dari drum plastik dengan volume total $180 \mathrm{~L}$, dilengkapi dengan keran dan tutup. Sedangkan anaerobic trickling reactor terbuat dari pipa acrylic dan dilengkapi dengan saluran inlet dan outlet substrat, saluran gas, perforated plate yang berfungsi untuk meratakan distribusi substrat di dalam reaktor, pompa, gas holder untuk menampung gas dengan ukuran $30 \times 30$ $\mathrm{cm}$, keran, akumulator (digunakan sebagai tempat untuk menampung substrat sebelum dan setelah masuk anaerobic trickling reactor) dan selang. Tinggi total reaktor anaerobic trickling yaitu $100,6 \mathrm{~cm}$ dengan diameter dalam $4,5 \mathrm{~cm}$ dan diameter luar $5 \mathrm{~cm}$. Akumulator yang digunakan terbuat dari pipa PVC diameter 3 " ( 3 inchi), tinggi total $20,5 \mathrm{~cm}$, volume total $935 \mathrm{~mL}$, dan volume operasional $750 \mathrm{~mL}$, dilengkapi dengan saluran inlet, outlet, dan gas. Bahan isian atau media untuk ketiga anaerobic trickling reactor berbeda-beda yaitu bioball rambutan (anaerobic trickling reactor 1 ), bioball bola (anaerobic trickling reactor 2 ) dan media sedotan (anaerobic trickling reactor 3). Media-media ini dipilih karena mudah didapatkan, harganya terjangkau tahan lama, dan tidak mudah terdegradasi secara biologi (berbahan dasar plastik). Bahan isian yang berbeda-beda ini untuk memvariasikan luas permukaan media pada setiap anaerobic trickling reactor. Penggunaan 
media yang berbeda ini untuk melihat pengaruh luas permukaan media terhadap kinerja masing-masing anaerobic trickling reactor selama seeding dan aklimatiasi. Adapun spesifikasi media yang digunakan pada ketiga anaerobic trickling reactor dapat dilihat pada Tabel 1. Adapun skema reaktor yang digunakan pada penelitian ini dapat dilihat pada Gambar 1. dan reaktor hidrolisis serta anaerobic trickling reactor dapat dilihat pada Gambar 2.

Tabel 1. Spesifikasi Bahan Isian pada Setiap Anaerobic Trickling Reactor

\begin{tabular}{|c|c|c|c|}
\hline & \multicolumn{3}{|c|}{ Anaerobic Trickling Reactor } \\
\hline Parameter & 1 & 2 & 3 \\
\hline Jenis media & Biobal/Rambutan & Biobal/Bola & Sedotan (Straws) \\
\hline Diameter media & $4 \mathrm{~cm}$ & $3 \mathrm{~cm}$ & $0,6 \mathrm{~cm}$ \\
\hline Panjang media & - & - & $1,2 \mathrm{~cm}$ \\
\hline $\begin{array}{l}\text { Luas permukaan } \\
\text { media }\end{array}$ & $\begin{array}{l}70,75 \mathrm{~cm}^{2} \\
32 \text { buah }\end{array}$ & $77,28 \mathrm{~cm}^{2}$ & $\begin{array}{c}4,52 \mathrm{~cm}^{2} \\
1.680 \text { buah }\end{array}$ \\
\hline $\begin{array}{l}\text { Jumlah Media di } \\
\text { dalam reaktor }\end{array}$ & $2.264 \mathrm{~cm}^{2}$ & $3.789 \mathrm{~cm}^{2}$ & $7.594 \mathrm{~cm}^{2}$ \\
\hline $\begin{array}{l}\text { Luas permukaan } \\
\text { total media }\end{array}$ & & & \\
\hline Gambar media & & & \\
\hline
\end{tabular}

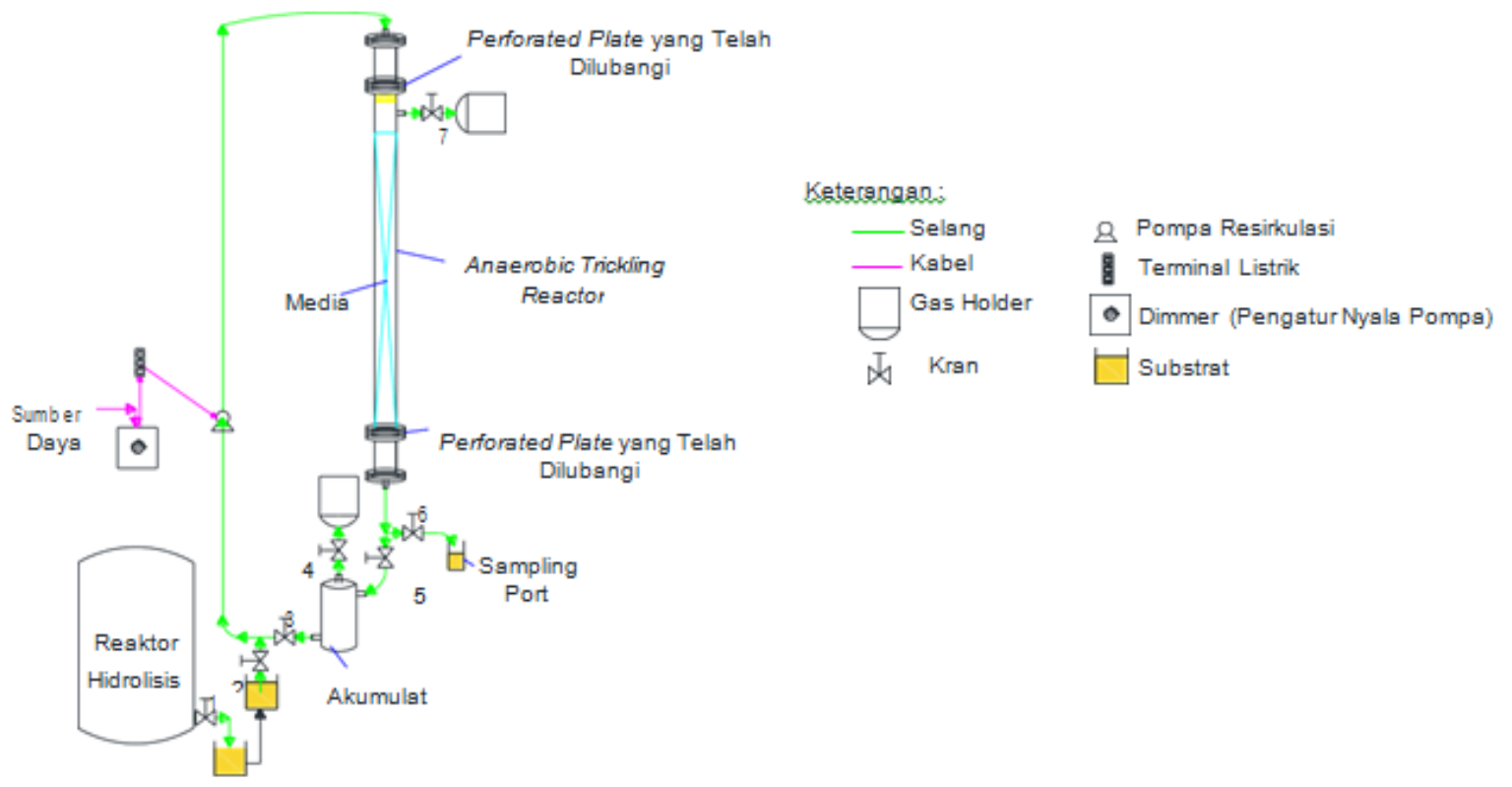

Sumber : Hasil Pengukuran, 2017.

Gambar 1. Skema Reaktor 
Pada Gambar 1., substrat yang diperoleh dari reaktor hidrolisis dimasukkan ke dalam anaerobic trickling reactor menggunakan pompa. Saat memasukkan substrat, keran 3 pada bagian bawah akumulator ditutup dan keran 2 dibuka. Setelah substrat selesai dimasukkan, keran 2 ditutup dan keran 3 dibuka, kemudian dilakukan sirkulasi substrat. Pengambilan sampel dilakukan pada sampling port. Kecepatan pompa diatur menggunakan dimmer.

\section{Semarta, Hartati, Salafudin}

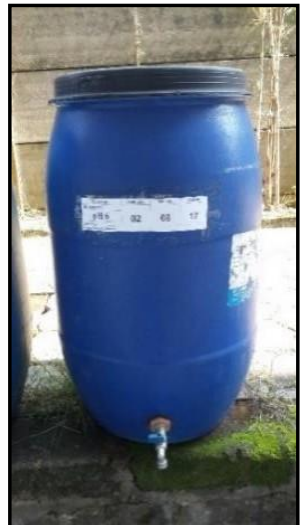

(a)

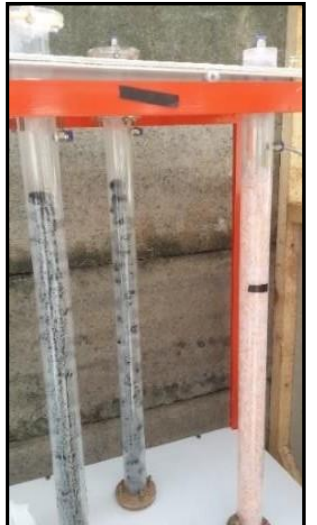

(b)

Gambar 2. (a) Reaktor Hidrolisis dan (b) Anaerobic Trickling Reactor

\subsection{Bahan}

Bahan yang digunakan dalam penelitian meliputi sampah rumah makan yang diperoleh dari kegiatan Rumah Makan SP Jalan Sekepanjang 3 No. 55 Bandung. Penggunaan Sampah rumah makan karena sampah ini sebagian besar terdiri dari sampah biodegradable. Menurut Mokobombang dan Rahardyan (2013), sampah rumah makan di Kota Bandung memiliki kadar volatil sebesar 72,39 \%. Sampah organik dengan kadar volatil yang tinggi menunjukkan bahwa sampah organik kaya akan bahan yang mudah didekomposisi oleh mikroorganisme (Oktaviani, 2008). Bahan lain yang digunakan dalam penelitian yaitu air pembilas (air pelarut) berupa air keran yang diperoleh di Jurusan Teknik Lingkungan Itenas Bandung, kotoran sapi diperoleh dari peternakan sapi di daerah Pasir Impun Bandung, dan lumpur air limbah domestik diambil dari selokan di Kompleks Perumahan Cikutra Baru Bandung. Kotoran sapi dan lumpur air limbah domestik ini digunakan sebagai bahan baku pembuatan cairan manure untuk inokulum proses anaerob di anaerobic trickling reactor. Pemilihan ketiga lokasi ini karena jaraknya yang dekat dengan lokasi penelitian.

\subsubsection{Pembuatan Substrat Cairan Sampah Organik}

Sampah rumah makan yang telah diambil, dipisahkan antara organik dan anorganik. Kemudian sampah organik diukur densitas, dicacah dan dimasukkan ke reaktor hidrolisis. Sampah organik yang digunakan juga diukur karakteristik awalnya seperti kadar air, kadar volatil, karbon organik, dan nitrogen total kjeldahl. Di dalam reaktor hidrolisis sampah organik dicampur air pembilas dengan rasio volume 1:1, karena berdasarkan literatur Liberty (2008) dalam Khairani, dkk. (2015), rasio sampah organik dengan air 1:1 memiliki kondisi yang optimal dalam proses anaerob (rasio $\mathrm{C}: \mathrm{N}: \mathrm{P}$ ). Berdasarkan data karakteristik awal sampah diperoleh densitas sampah organik sebesar $0,798 \mathrm{~kg} / \mathrm{L}$, sehingga perbandingan antara sampah organik dengan air pembilas yang dimasukkan ke reaktor hidrolisis yaiitu 12:15 (w/w). Hasil pencampuran keduanya menghasilkan cairan sampah organik yang kemudian dipakai sebagai substrat. Selama proses di reaktor hidrolisis, dilakukan pengukuran parameter $\mathrm{pH}$ dan temperatur (setiap hari), COD (Chemical Oxygen Demand), TAV (Total Asam Volatil), dan 
alkalinitas (dua hari sekali). Proses ini berlangsung sampai hari ke-46. Selanjutnya substrat di panen dan diukur karakteristik awal substrat sebelum digunakan untuk proses aklimatisasi.

\subsubsection{Pembuatan Cairan Manure}

Mikroorganisme yang digunakan pada penelitian ini menggunakan kultur campuran yang berasal dari cairan manure yaitu campuran antara kotoran sapi, air keran, dan lumpur air limbah domestik dengan rasio 1:2:1. Penentuan rasio kotoran sapi dengan air ini berdasarkan penelitian Anggraini, dkk., 2015, dimana penambahan lumpur air limbah domestik dilakukan untuk memperbanyak jenis mikroorganisme.

\subsection{Seeding dan Aklimatisasi}

Proses seeding dan aklimatisasi dilakukan di dalam anaerobic trickling reactor. Saat seeding media direndam dengan cairan manure serta dilakukan pengukuran $\mathrm{pH}$ dan temperatur. Selain itu, dilakukan juga pengukuran berat media sebelum dan sesudah direndam cairan manure, namun media direndam cairan manure pada wadah tertutup di luar anaerobic trickling reactor dengan perlakuan yang sama. Saat aklimatisasi, dilakukan penambahan substrat ke dalam reaktor dan reaktor dioperasikan dengan sistem trickling. Selama proses aklimatisasi dilakukan pengukuran pH, temperatur, dan COD (Chemical Oxygen Demand). Setelah proses seeding dan aklimatisasi selesai dilakukan juga pengukuran konsentrasi biogas yang terbentuk. Pengukuran konsentrasi dan volume biogas dilakukan saat proses seeding dan aklimatisasi selesai.

\subsection{Pengukuran Karakteristik Sampel}

Jenis parameter yang diukur selama penelitian, metode yang digunakan, dan tahap pengukuran dapat dilihat pada Tabel 2.

\begin{tabular}{|c|c|c|c|}
\hline Jenis Parameter & Metode & Tahap Pengukuran & Sumber \\
\hline $\mathrm{pH}$ & $\begin{array}{c}\text { Elektroda } \\
\text { Potensiometri }\end{array}$ & $\begin{array}{c}\text { Karakteristik air pembilas, karakteristik } \\
\text { substrat di reaktor hidrolisis, seeding } \\
\text { dan aklimatisasi }\end{array}$ & $\begin{array}{c}\text { SNI 06- } \\
6989.11-2004\end{array}$ \\
\hline Temperatur & Potensiometri & $\begin{array}{c}\text { Karakteristik air pembilas, karakteristik } \\
\text { substrat di reaktor hidrolisis, seeding } \\
\text { dan aklimatisasi }\end{array}$ & $\begin{array}{c}\text { SNI 06- } \\
6989.11-2004\end{array}$ \\
\hline Densitas sampah & Gravimetri & Karakteristik sampah organik & $\begin{array}{c}\text { SNI 19-3964- } \\
1995\end{array}$ \\
\hline Kadar air sampah & Gravimetri & Karakteristik sampah organik & $\begin{array}{c}\text { SNI 03-1971- } \\
1990\end{array}$ \\
\hline $\begin{array}{l}\text { Kadar volatil } \\
\text { sampah }\end{array}$ & Gravimetri & Karakteristik sampah organik & $\begin{array}{c}\text { SMEWW } \\
2540 \mathrm{E}, 2012\end{array}$ \\
\hline $\begin{array}{l}\text { Karbon organik } \\
\text { (C-Organik) }\end{array}$ & Refluks Terbuka & Karakteristik sampah organik & $\begin{array}{c}\text { SMEWW } \\
5220 B, 2012\end{array}$ \\
\hline $\begin{array}{l}\text { Nitrogen Total } \\
\text { Kjeldahl (NTK) }\end{array}$ & Kjeldahl Analyzer & Karakteristik sampah organik & $\begin{array}{c}\text { SNI } \\
2801: 2010\end{array}$ \\
\hline Alkalinitas & Titrasi Asam-Basa & $\begin{array}{c}\text { Karakteristik substrat di reaktor } \\
\text { hidrolisis }\end{array}$ & $\begin{array}{c}\text { SNI 06-2422- } \\
1991\end{array}$ \\
\hline $\begin{array}{l}\text { Total Asam Volatil } \\
\text { (TAV) }\end{array}$ & $\begin{array}{l}\text { Destilasi dan } \\
\text { Titrimetri }\end{array}$ & $\begin{array}{c}\text { Karakteristik substrat di reaktor } \\
\text { hidrolisis }\end{array}$ & $\begin{array}{c}\text { SMEWW } \\
\text { 5560C, } 2012 .\end{array}$ \\
\hline $\begin{array}{l}\text { Chemical Oxygen } \\
\text { Demand (COD) }\end{array}$ & $\begin{array}{l}\text { Refluks Tertutup, } \\
\text { Titrimetri }\end{array}$ & $\begin{array}{c}\text { Karakteristik air pembilas, karakteristik } \\
\text { substrat di reaktor hidrolisis, seeding } \\
\text { dan aklimatisasi }\end{array}$ & $\begin{array}{l}\text { SMEWW } \\
\text { 5220C, } 2012\end{array}$ \\
\hline Konsentrasi Biogas & $\begin{array}{c}\text { Gas } \\
\text { Chromatography }\end{array}$ & Seeding dan aklimatisasi & - \\
\hline
\end{tabular}

\section{HASIL DAN PEMBAHASAN}

\subsection{Karakteristik Sampah Organik Rumah Makan dan Air Pembilas}


Pengukuran karakteristik sampah organik rumah makan dan air pembilas dilakukan untuk mengetahui apakah sampah organik dan air pembilas dapat digunakan untuk proses anaerob atau tidak. Adapun hasil pengukuran karakteristik sampah organik dan air pembilas dapat dilihat pada Tabel 3.

Tabel 3. Karakteristik Sampah Organik dan Air Pembilas

\begin{tabular}{ccccccc}
\hline \multirow{2}{*}{ No. } & \multicolumn{2}{c}{ Karakteristik Sampah Organik } & \multicolumn{3}{c}{ Karakteristik Air Pembilas } \\
\cline { 2 - 7 } & Parameter & Hasil & Satuan & Parameter & Hasil & Satuan \\
\hline 1 & Densitas & 0,798 & $\mathrm{~kg} / \mathrm{L}$ & $\mathrm{pH}$ & 7,45 & - \\
\hline 2 & Kadar Air & 74,95 & $\%$ berat basah & Temperatur & 28,9 & ${ }^{\circ} \mathrm{C}$ \\
\hline 3 & Kadar Volatil & 86,92 & $\%$ berat kering & $\mathrm{COD}$ & 46,85 & $\mathrm{mg} \mathrm{O}_{2} / \mathrm{L}$ \\
\hline 4 & Karbon Organik & 50,04 & $\%$ berat kering & & & \\
\hline 5 & Total Nitrogen & 2,24 & $\%$ berat kering & & & \\
\hline 6 & C/N & 22,33 & - & & & \\
Sumber : Hasil Pengukuran, 2017. & & & & &
\end{tabular}

Densitas sampah organik yang dipakai sebesar 0,798 kg/L. Menurut Rees (1980), kecepatan penyerapan karbon oleh mikroorganisme sangat dipengaruhi oleh densitas sampah organik. Densitas sampah organik yang baik untuk mempercepat penyerapan karbon oleh mikroorganisme yaitu 0,5-1 kg/L (Rees, 1980). Kadar air dan kadar volatil sampah organik yang terukur berturut-turut sebesar 74,95\% dan 86,92\%. Menurut Tchobanoglous (1993), kadar air garbage sekitar 50-80\% dan kadar volatil garbage 95\%. Kadar air dan kadar volatil sampah makanan (food waste) dari kegiatan cafe atau rumah makan di Kota Bandung yaitu sebesar 70,87\% dan 72,39\% (Mokobombang dan Rahardyan, 2013) Kadar air yang tinggi memudahkan sampah organik untuk didekomposisi oleh mikroorganisme, sedangkan kadar volatil yang tinggi menunjukkan bahwa sampah organik kaya akan materi yang mudah di dekomposisi oleh mikroorganisme.

Kadar karbon organik dari sampah organik yang digunakan sebesar 50,04 \%. Menurut Mokobombang dan Rahardyan (2013), kandungan karbon organik sampah makanan dari kegiatan cafe atau rumah makan di Kota Bandung sebesar 72,60 \%. Tingginya kandungan karbon organik ini menunjukkan potensi yang besar dalam pengolahan secara anaerob. Kadar total nitrogen sampah organik yang digunakan sebesar 2,24\%. Nilai ini mendekati perolehan kadar total nitrogen untuk sampah makanan dari kegiatan cafe atau rumah makan di Kota Bandung yaitu sebesar 2,1 \% (Mokobombang dan Rahardyan, 2013). Kandungan nitrogen yang tinggi menjadi potensi pertumbuhan mikroorganisme karena nitrogen merupakan nutrien penting untuk mikroorganisme. Rasio C/N sampah organik yang digunakan yaitu 22,33 (Tabel 3.). Menurut Polprasert (1996), rasio $C / N$ untuk proses anaerob berkisar antara 20:1 hingga 30:1. Sehingga nilai rasio $\mathrm{C} / \mathrm{N}$ sampah organik yang digunakan masih memenuhi kriteria.

Dilihat dari hasil pengukuran karakteristik awal air pembilas untuk reaktor hidrolisis (Tabel 3.), $\mathrm{COD}$ air pembilas yaitu sebesar $46,85 \mathrm{mg} \mathrm{O}_{2} / \mathrm{L}$. COD menunjukkan kandungan organik yang ada dalam air pembilas. Menurut Grady dan Henry (1990), proses penguraian anaerob berlangsung optimum pada pH 6 hingga 8 dan pada temperatur termofilik (diatas $55^{\circ} \mathrm{C}$ ), namun proses anaerob saat kondisi termofilik pada beberapa percobaan tidak memperoleh hasil yang memuaskan karena memiliki kekurangan yaitu diperlukannya energi tambahan. Sehingga sebagian besar percobaan anaerob menggunakan temperatur mesofilik dalam pengoperasiannya $\left(20-55^{\circ} \mathrm{C}\right.$ ) (Grady dan Henry, 1990). Nilai pH air pembilas yang digunakan netral yaitu sebesar 7,45 dengan temperatur $28,9^{\circ} \mathrm{C}$. Hal ini menunjukkan baik $\mathrm{pH}$ maupun temperatur air pembilas dapat digunakan untuk proses anaerob.

\subsection{Karakteristik Substrat pada Reaktor Hidrolisis}

Substrat yang digunakan pada penelitian ini yaitu substrat cairan sampah organik. Substrat yang akan digunakan terlebih dahulu dikondisikan secara alami di reaktor hidrolisis. Pengkondisian yang dimaksud adalah mengkondisikan substrat agar $\mathrm{pH}$ yang ingin digunakan tercapai. Proses ini berlangsung sampai hari ke-46. Selanjutnya substrat di panen dan 
digunakan untuk proses aklimatisasi. Selama berada di reaktor ini diukur parameter $\mathrm{pH}$, temperatur, COD, TAV, dan alkalinitas.

\subsubsection{Temperatur dan COD}

Gambar 3.a, memperlihatkan hasil pengukuran temperatur substrat sampah organik pada reaktor hidrolisis berada pada rentang kondisi mesofilik $\left(22-55^{\circ} \mathrm{C}\right)$. Menurut Grady dan Henry (1990), temperatur dalam kondisi termofilik (diatas $55^{\circ} \mathrm{C}$ ) merupakan kondisi optimum dalam proses anaaerob, namun mempunyai kelemahan yaitu dibutuhkannya energi tambahan untuk menjaga temperatur berada pada kondisi termofilik. Oleh karena itu, sebagian besar percobaan proses anaerobik menggunakan temperatur mesofilik $\left(20-55^{\circ} \mathrm{C}\right)$ dalam pengoperasiannya. Sehingga kondisi di reaktor hidrolisis sesuai dengan literatur.

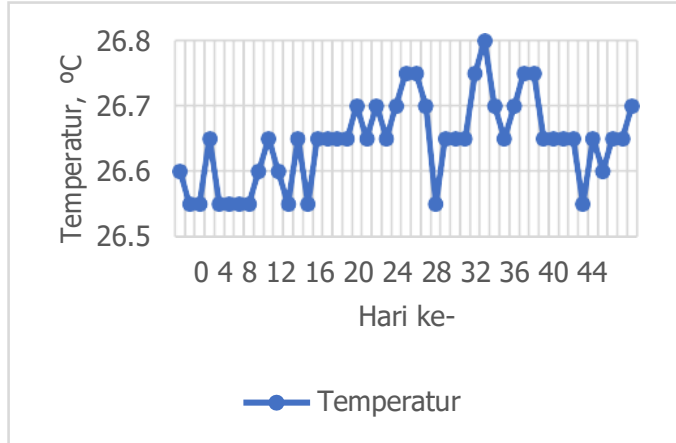

(a)

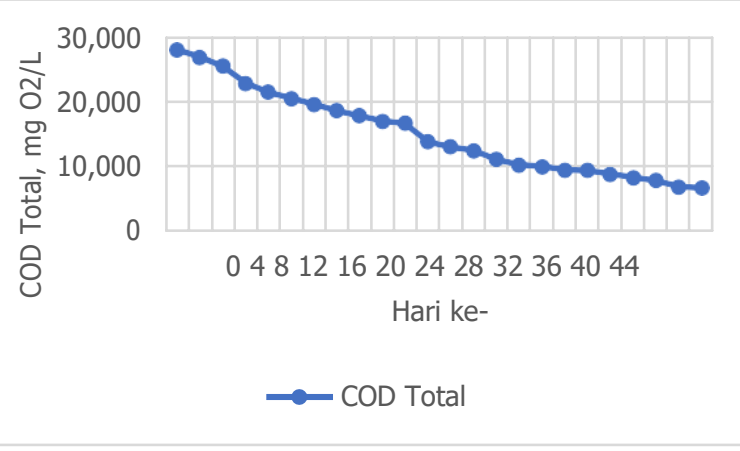

(b)

Gambar 3. Parameter (a) Temperatur dan (b) COD Substrat di Reaktor Hidrolisis (Sumber : Hasil Pengukuran, 2017)

Gambar 3.b, memperlihatkan hasil pengukuran untuk COD total pada substrat sampah organik di reaktor hidrolisis. Saat hari ke-0, nilai konsentrasi COD total untuk reaktor hidrolisis sebesar $28.032 \mathrm{mg} \mathrm{O} / \mathrm{L}$. Kondisi konsentrasi COD total hari ke-0 hingga hari ke-46 menunjukkan grafik yang menurun. Nilai COD total pada hari ke-46 sebesar $6.432 \mathrm{mg} \mathrm{O}_{2} / \mathrm{L}$. Menurut (Malina dan Pohland, 1992), COD yang cocok untuk proses anaerob yaitu berkisar antara $1.000-30.000 \mathrm{mg} / \mathrm{L}$. Penurunan nilai COD total pada reaktor hidrolisis menunjukkan adanya aktifitas mikroorganisme dalam mendegradasi senyawa organik. Semakin banyak jumlah mikroorganisme, maka semakin banyak materi atau senyawa organik yang disisihkan (Ramadanthi, 2008).

\subsubsection{Total Asam Volatil (TAV), pH, dan Alkalinitas}

Gambar 4.a., memperlihatkan hasil pengukuran TAV substrat lindi sampah organik di reaktor hidrolisis. Konsentrasi TAV terbesar untuk reaktor hidrolisis yaitu pada hari ke-18 sebesar $9.805,99 \mathrm{mg} / \mathrm{L}$ asetat. Terjadinya peningkatan konsentrasi TAV di reaktor hidrolisis rentang hari ke-0 hingga hari ke-18 akibat fase hidrolisis-asidogenesis, karena pada rentang waktu tersebut terbentuk asam dalam jumlah yang banyak. Menurut Eckenfelder, dkk. (1988) dalam Hanupurti (2009), jika akumulasi asam volatil melebihi $2.000 \mathrm{mg} / \mathrm{L}$ akan menyebabkan terhambatnya pembentukkan gas metan, serta akumulasi asam volatil menunjukkan bahwa pertumbuhan bakteri metanogen yang tidak aktif. Setelah hari ke-18, nilai konsentrasi TAV mulai menunjukkan penurunan. 


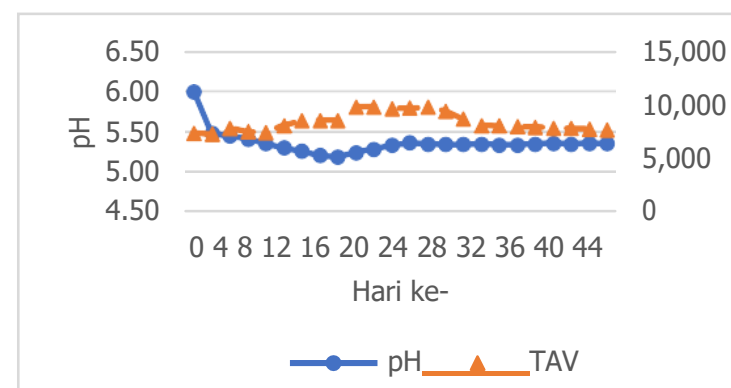

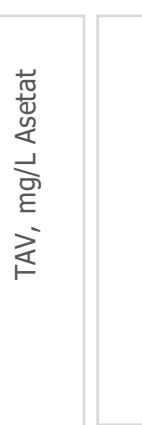

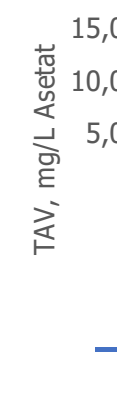

\section{(a) \\ Gambar 4. Hubungan Parameter (a) pH dengan TAV, dan (b) TAV dengan TAV/Alkalinitas Substrat di Reaktor Hidrolisis \\ (Sumber : Hasil Pengukuran, 2017)}

Saat awal nilai pH mengalami penurunan pada reaktor hidrolisis (Gambar 4.a). Hal ini terjadi karena adanya proses hidrolisis-asidogenesis yang menyebabkan turunnya nilai $\mathrm{pH}$. Saat hari ke-0, nilai pH untuk reaktor hidrolisis yaitu 6,00 hingga hari ke-18 mengalami penurunan menjadi 5,24. Hal ini berbanding terbalik dengan konsentrasi TAV. Semakin tinggi konsentrasi TAV, maka semakin rendah nilai $\mathrm{pH}$, karena TAV menunjukkan adanya asam-asam organik di dalam reaktor yang menyebabkan menurunnya nilai $\mathrm{pH}$. TAV dapat mempengaruhi $\mathrm{pH}$ jika alkalinitas tidak memadai (Ramadanthi, 2008). Menurut Polprasert (1996), saat tahap asidogenesis terjadi pembentukan asam volatil yang cenderung akan menurunkan $\mathrm{pH}$ karena kapasitas penyangga sistem tidak mampu mempertahankan pH sistem. Gambar 4.b., menunjukkan hubungan antara nilai konsentrasi TAV dengan rasio TAV:alkalinitas. Nilai rasio TAV:alkalinitas dibawah 0,4 menandakan buffer bisa menjaga pH tidak turun secara drastis (Grady dan Henry, 1990). Hasil pengukuran yang di dapat untuk ketiga reaktor hidrolisis, nilai rasio TAV:alkalinitas diatas 0,4 . Tingginya rasio ini mengakibatkan turunnya nilai $\mathrm{pH}$ di dalam sistem akibat dari meningkatnya konsentrasi TAV.

\subsection{Seeding dan Aklimatisasi}

Proses seeding menggunakan cairan manure sebagai inokulum atau sumber mikroorganisme untuk pembentukan biofilm dan selama proses aklimatisasi dilakukan penambahan substrat yang diperoleh dari reaktor hidrolisis. Adapun karakteristik awal substrat dan cairan manure yang digunakan dapat dilihat pada Tabel 4.

Tabel 4. Karakteristik Awal Substrat dan Cairan Manure

\begin{tabular}{|c|c|c|c|}
\hline \multirow{2}{*}{ No. } & \multirow{2}{*}{ Parameter } & \multicolumn{2}{|c|}{ Hasil Pengukuran Karakteristik Awal } \\
\hline & & Substrat & Cairan Manure \\
\hline 1 & $\mathrm{pH}$ & 5,35 & 6,87 \\
\hline 2 & Temperatur & $26,70^{\circ} \mathrm{C}$ & $27,15^{\circ} \mathrm{C}$ \\
\hline 3 & COD total & $6.720,00 \mathrm{mg} \mathrm{O}_{2} / \mathrm{L}$ & $6297,6 \mathrm{mg} / \mathrm{L}$ \\
\hline 4 & BOD & $5.872,24 \mathrm{mg} / \mathrm{L}$ & - \\
\hline 5 & $\mathrm{BOD} / \mathrm{COD}$ & 0,84 & - \\
\hline 6 & TAV & $7.671,66 \mathrm{mg} / \mathrm{L}$ asetat & - \\
\hline 7 & Alkalinitas total & $7.019,18 \mathrm{mg} / \mathrm{L}$ & - \\
\hline 8 & TAV/alkalinitas total & 1,09 & - \\
\hline
\end{tabular}

\subsubsection{Seeding}

Proses seeding pada penelitian ini dilakukan selama 31 hari (memaksimalkan pembentukan biofilm). Selama tahap ini, dilakukan pergantian cairan manure sebanyak $100 \mathrm{~mL}$ setiap dua 
hari sekali. Fungsinya untuk menjaga ketersedian mikroorganisme. Parameter yang diukur meliputi pH dan temperatur cairan manure di dalam reaktor, serta berat media sebelum dan sesudah direndam dengan cairan manure. Berdasarkan hasil pengukuran pada Gambar 5.a dan Gambar 5.b, nilai pH cairan manure tiap-tiap anaerobic trickling reactor berada pada kisaran $\mathrm{pH} 6,87$ hingga $\mathrm{pH} 7,52$, sedangkan temperaturnya berada pada rentang $27^{\circ} \mathrm{C}$ hingga $28^{\circ} \mathrm{C}$. Rentang $\mathrm{pH}$ optimum untuk proses anaerob, berjalan pada kisaran $\mathrm{pH} 6$ sampai 8 , sedangkan sebagian besar percobaan proses anaerobik menggunakan temperatur mesofilik dalam pengoperasiannya $\left(20-55^{\circ} \mathrm{C}\right)$ (Grady dan Henry, 1990). Berdasarkan hasil pengukuran berat media sebelum dan sesudah seeding, ketiga jenis media mengalami pertambahan berat rata-rata sebesar 0,5421 gram/media (12,93\%) (bioball rambutan), 0,7158 gram/media (bioball bola) $(11,47 \%)$, dan 0,0449 gram/media (media straws) (13,95 \%). Adanya pertambahan berat ini menunjukkan pertumbuhan mikroorganisme membentuk biofilm pada permukaan tiap media.

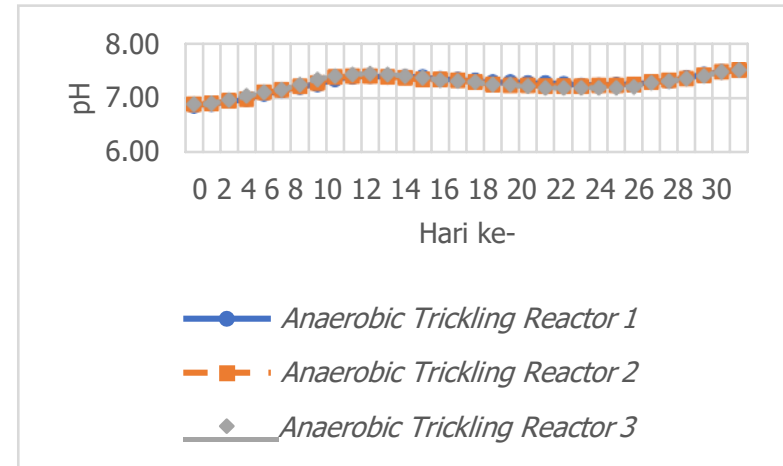

(a)

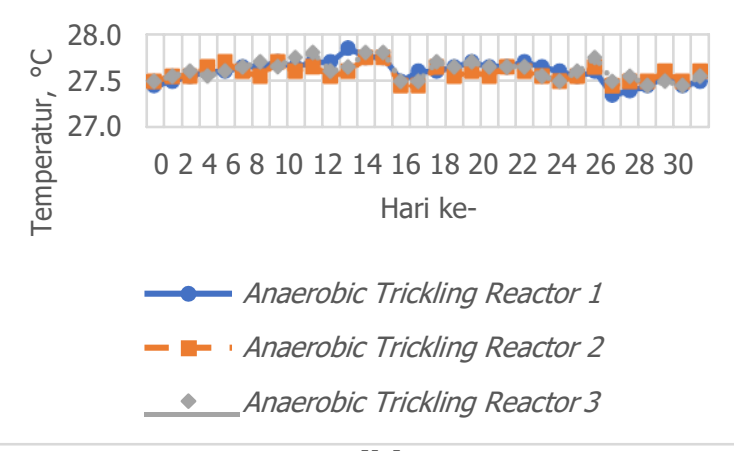

(b)

Gambar5. Parameter(a) pH dan (b)Temperatur pada Anaerobic Trickling Reactor saat Proses Seeding

(Sumber : Hasil Pengukuran, 2017)

\subsubsection{Aklimatisasi}

Saat aklimatisasi, cairan manure dari proses seeding disisakan sebesar $750 \mathrm{~mL}$ sesuai kapasitas operasional akumulator yang digunakan, kemudian dilakukan penambahan dan pengurangan substrat cairan sampah organik sedikit demi sedikit sebesar $75 \mathrm{~mL}$. Fungsi penambahan substrat secara perlahan ini agar mikroorganisme yang telah tumbuh dapat beradaptasi terlebih dahulu dengan substrat yang ditambahkan. Proses aklimatisasi pada penelitian ini dilakukan selama 20 hari (sampai terjadi steady state). Selama proses aklimatisasi, dilakukan pengukuran parameter $\mathrm{pH}$, temperatur, dan COD.

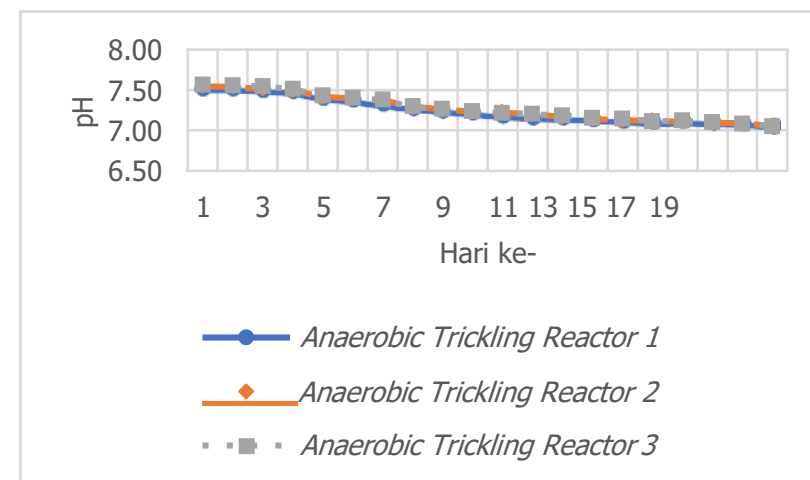

(a)

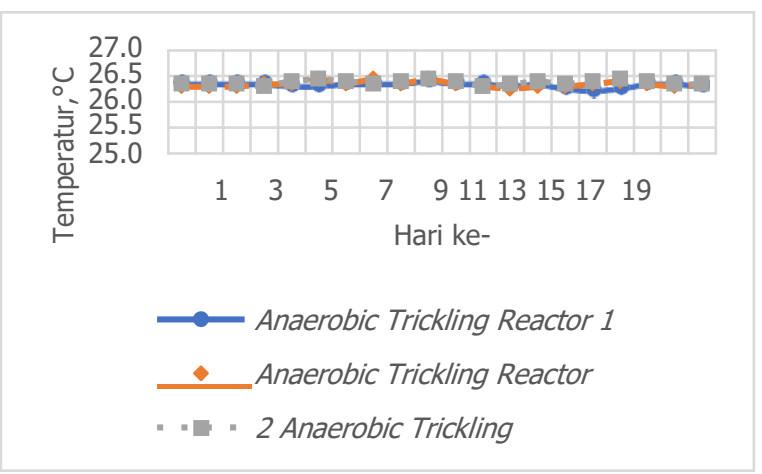

(b)

Gambar 6. Grafik Hasil Pengukuran (a) pH dan (b) Temperatur pada Anaerobic Trickling Reactor saat Proses Aklimatisasi

(Sumber : Hasil Pengukuran, 2017) 
Menurut Grady dan Henry (1990), penguraian anaerob berjalan optimum pada rentang pH 6 hingga $\mathrm{pH}$ 8. Berdasarkan hasil pengukuran $\mathrm{pH}$ saat proses aklimatisasi di ketiga anaerobic trickling reactor (dapat dilihat pada Gambar 6.a.), memperlihatkan nilai pH hari ke-0 untuk tiap anaerobic trickling reactor berturut-turut sebesar 7,50, 7,55, dan 7,57, sedangkan saat hari ke-20 nilai pH berturut-turut sebesar 7,05, 7,06, dan 7,05. pH pada ketiga anaerobic trickling reactor berada pada kondisi optimum untuk proses anaerob. Berdasarkan hasil pengukuran temperatur pada Gambar 6.b., temperatur di ketiga anaerobic trickling reactor selama proses aklimatisasi stabil berada pada rentang $26^{\circ} \mathrm{C}$ hingga $26,5^{\circ} \mathrm{C}$. Kondisi temperatur berada pada rentang temperatur mesofilik (rentang temperatur $20-50^{\circ} \mathrm{C}$ ), sehingga berada pada temperatur yang sesuai untuk proses anaerob. Menurut Buekens (2005) dalam Oktaviani (2008), menjaga temperatur dalam keadaan stabil lebih penting daripada menjaga temperatur dalam keadaan optimum.

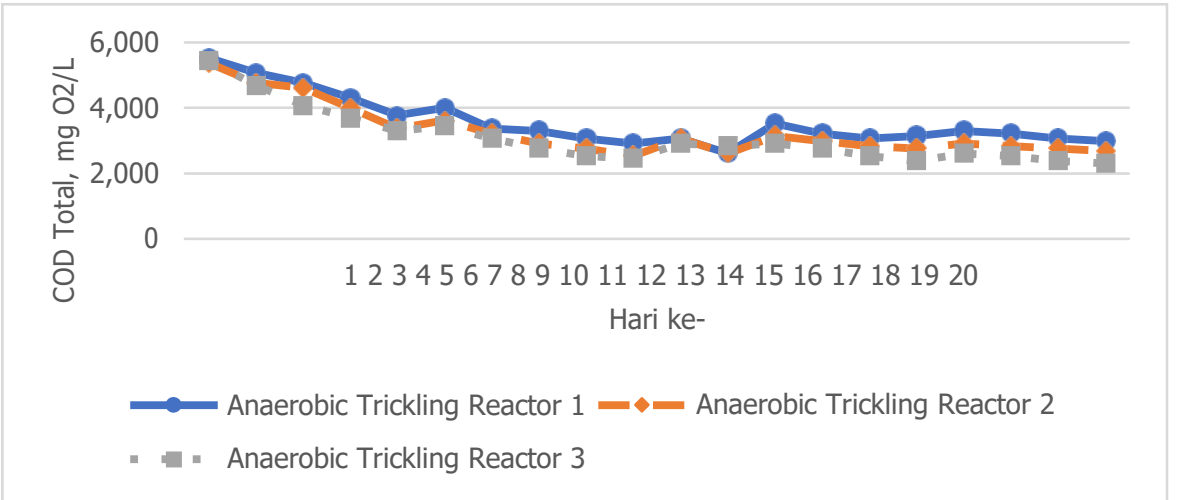

\section{Gambar 7. GrafikHasil Pengukuran COD pada Anaerobic Trickling Reactor saat Proses Aklimatisasi \\ (Sumber : Hasil Pengukuran, 2017)}

Konsentrasi COD total dari hari ke-1 sampai dengan hari ke-20 mengalami penurunan (Gambar 7.). Hal ini terjadi akibat adanya proses degradasi senyawa organik oleh mikroorganisme. Untuk anaerobic trickling reactor 1 pada hari ke-1, konsentrasi COD sebesar $5.529,60 \mathrm{mg} \mathrm{O}_{2} / \mathrm{L}$ sedangkan pada hari ke-20 sebesar 2.995,20 mg $\mathrm{O}_{2} / \mathrm{L}$. Untuk anaerobic trickling reactor 2 , pada hari ke-1, konsentrasi COD sebesar $5.376,00 \mathrm{mg} \mathrm{O} / \mathrm{L}$ sedangkan pada hari ke-20 sebesar $2.688,00 \mathrm{mg} \mathrm{O}_{2} / \mathrm{L}$. Untuk anaerobic trickling reactor 3 , pada hari ke1 , konsentrasi COD sebesar $5.452,80 \mathrm{mg} \mathrm{O} / \mathrm{L}$ sedangkan pada hari ke-20 sebesar $2.304,00$ $\mathrm{mg} \mathrm{O}_{2} / \mathrm{L}$. Menurut Herald (2010) dalam Ananda (2016), proses aklimatisasi dikatakan selesai ketika penurunan COD telah konstan. Penurunan konsentrasi COD yang konstan pada ketiga anaerobic trickling reactor terjadi pada hari ke-14 hingga harike-20.

\section{Konsentrasi Biogas Selama Seeding dan Aklimatisasi}

Terbentuknya biogas saat seeding dan aklimatisasi menandakan adanya aktifitas mikroorganisme anaerob dalam mendegradasi bahan organik. Menurut Hermawan, dkk. (2007), biogas dihasilkan dari fermentasi organik oleh bakteri anaerob. Pengukuran konsentrasi biogas dilakukan saat seeding dan aklimatisasi berakhir (hari ke-31 dan hari ke20). Pengukuran konsentrasi biogas menggunakan alat Gas Chromatograph. Adapun hasil pengukuran konsentrasi biogas saat seeding dan aklimatisasi dapat dilihat pada Tabel 5. 
Tabel 5. Konsentrasi Biogas saat Seeding dan Aklimatisasi

\begin{tabular}{ccccccc}
\hline & \multicolumn{7}{c}{ Konsentrasi (\%) } \\
\cline { 2 - 7 } Jenis Gas & ATR 1 & ATR 2 & ATR 3 & ATR 1 & ATR 2 & ATR 3 \\
\cline { 2 - 7 } & 99,66 & 89,06 & 89,31 & 98,34 & 90,28 & 100,0 \\
\cline { 2 - 7 } $\mathrm{CO}_{2}$ & - & - & - & - & - & - \\
$\mathrm{H}_{2}$ & - & - & - & - & - & - \\
$\mathrm{N}_{2}$ & - & - & - & - & - & - \\
$\mathrm{O}_{2}$ & 0,34 & 10,94 & 10,69 & 1,66 & 9,72 & - \\
$\mathrm{CH}_{4}$ & & &
\end{tabular}

Keterangan : ATR $=$ Anaerobic Trickling Reactor

Sumber : Hasil Pengukuran, 2017.

Konsentrasi gas hidrogen, nitrogen, dan oksigen tidak terdeteksi (0\%). Menurut Oktaviani (2008), hidrogen terbentuk pada tahap pembentukan asam, sedangkan oksigen merupakan gas yang bukan berasal dari proses. Tidak terbentuknya gas hidrogen selama seeding dan aklimatisasi disebabkan karena kondisi $\mathrm{pH}$ yang tidak sesuai untuk pembentukan hidrogen. Pembentukan hidrogen di dalam proses anaerob disebabkan oleh aktifitas bakteri asidogen dan asetogen. Menurut (Grady dan Henry, 1990), rentang pH untuk bakteri asidogen dapat tumbuh yaitu $\mathrm{pH} 5$ hingga $\mathrm{pH} 6,5$. Hasil pengukuran $\mathrm{pH}$ saat seeding dan aklimatisasi (Gambar 5.a dan Gambar 6.a), saat seeding rentang $\mathrm{pH} 6,87$ hingga 7,52 dan saat aklimatisasi rentang $\mathrm{pH} 7,05$ hingga 7,57. Karbondioksida $\left(\mathrm{CO}_{2}\right)$ terbentuk pada tahap pembentukan asam (asidogenesis dan asetogenesis) dan tahap pembentukan metana (metanogenesis), sedangkan metana $\left(\mathrm{CH}_{4}\right)$ terbentuk pada tahap metanogenesis. Menurut Polprasert (1996), rentang $\mathrm{pH}$ untuk pertumbuhan bakteri metanogen yaitu pada $\mathrm{pH} 6,6$ hingga 7,6 . Sehingga biogas yang banyak terbentuk selama tahap seeding dan aklimatisasi yaitu karbon dioksida $\left(\mathrm{CO}_{2}\right)$ dan metana.

\section{KESIMPULAN}

Selama proses seeding, $\mathrm{pH}$ cairan manure di anaerobic trickling reactor yaitu 6,87 hingga 7,52 , sedangkan temperaturnya yaitu pada rentang $27^{\circ} \mathrm{C}$ hingga $28^{\circ} \mathrm{C}$. Ketiga jenis media yang direndam cairan manure juga mengalami penambahan berat rata-rata sebesar 0,5421 gram/media (bioball rambutan) (12,93\%), (bioball rambutan), 0,7158 gram/media (bioball bola) $(11,47 \%)$, dan 0,0449 gram/media (media straws) $(13,95 \%)$. Pertambahan berat ini menunjukkan pertumbuhan mikroorganisme membentuk biofilm pada permukaan tiap media. Rentang pH selama proses aklimatisasi yaitu 7,05 hingga 7,57 , temperatur $26^{\circ} \mathrm{C}$ hingga $26,5^{\circ} \mathrm{C}$. Steady state saat aklimatisasi terjadi pada hari ke-14 hingga hari ke-20. Adanya aktifitas mikrooganisme saat proses seeding dan aklimatisasi ditandai dengan terbentuknya biogas yaitu $\mathrm{CO}_{2}$ dan $\mathrm{CH}_{4}$. Konsentrasi $\mathrm{CO}_{2}$ saat seeding di anaerobic trickling reactor 1, 2, dan 3 yaitu $99,6 \%$, 89,06 \%, dan 89,31\%, sedangkan saat aklimatisasi 98,34 \%, 90,28 \%, dan $100 \%$. Konsentrasi $\mathrm{CH}_{4}$ saat seeding pada setiap anaerobic trickling reactor yaitu 0,34 \%, 10,94 \%, dan $10,69 \%$, sedangkan saat aklimatisasi $1,66 \%$, 9,72 \%, dan $0 \%$. 


\section{DAFTAR RUJUKAN}

Ananda, R. A. (2016). Pengaruh Variasi Tekanan terhadap Peningkatan Konsentrasi Gas Methane dengan Teknologi Pressure Swing Absorption. Institut Teknologi Nasional Bandung, Bandung.

Andary, H. A., Oktiawan, W., \& Samudro, G. (2010). Studi Penurunan COD Dan Warna Pada Limbah Industri Tekstil Pt. Apac Inti Corpora dengan Kombinasi Anaerob-Aerob Menggunakan UASB dan HUASB. Universitas Diponegoro.

Anggraini, D., Pertiwi, M. B., \& Bahrin, D. (2015). Pengaruh Jenis Sampah, Komposisi Masukan dan Waktu Tinggal terhadap Komposisi Biogas dari Sampah Organik. Jurnal Teknik Kimia, 18(1).

Buekens, A. (2005). Energy recovery from residual waste by means of anaerobic digestion technologies. Paper presented at the Conference "The future of residual waste management in Europe.

Eckenfelder, W. W., Patoczka, J. B., \& Pulliam, G. W. (1988). Anaerobic Versus Aerobic Treatment In The USA. New York: Pergamon Press.

Grady, \& Henry, L. C. (1990). Biological Wastewater Treatment. New York: Marcel Dekker. Hanupurti, D. A. (2009). Kinetika Penyisihan Senyawa Organik Biowaste Fasa Cair dalam Upflow Anaerobic Fixed Bed Reactor (UAF-B) Bermedia Bambu. Institut Teknologi Bandung, Bandung.(444/S2-TL/TPAL/2009).

Herald, D. (2010). Pengaruh Variasi Rasio Waktu Reaksi terhadap Waktu Stabilisasi pada Penyisihan Senyawa Organik dari Air Buangan Pabrik Minyak Kelapa Sawit dengan Sequencing Batch Reactor Aerob. Universitas Andalas, Sumatera Barat.

Hermawan, B., Qodriyah, L., \& Puspita, C. (2007). Pemanfaatan Sampah Organik sebagai Sumber Biogas Untuk Mengatasi Krisis Energi Dalam Negeri. Universitas Lampung Bandar Lampung.

Indriyati, I. (2011). Proses Pembenihan (Seeding) dan Aklimatisasi Pada Reaktor Tipe Fixed Bed. Jurnal Teknologi Lingkungan, 4(2).

Khairani, R. M., Ainun, S., \& Hartati, E. (2015). Pemanfaatan Sampah Organik Pasar Sebagai Bahan Baku Biodigester. Institut Teknologi Nasional Bandung, Bandung.

Liberty, P. S. (2008). Pengaruh Penambahan Air pada Biowaste tehadap Rasio C:N:P dalam proses Mechanical Biological Treatment. Institut Teknologi Bandung, Bandung.

Malina, J. F., \& Pohland, F. G. (1992). Design of Anaerobic Processes for the Treatment of Industrial and Municipal Wastes. United States of America: Technomic.

Mokobombang, M. A., \& Rahardyan, B. (2013). Studi Awal Timbulan, Komposisi dan Karakteristik Food Waste. 1-11.

Oktaviani, D. (2008). Degradasi Biowaste dalam Reaktor Batch Anaerob sebagai Bagian dari Proses Mechanical Biological Treatment. Institut Teknologi Bandung, Bandung.

Polprasert, C. (1996). Organic Waste Recycling Second Edition. England: John Wiley and Sons.

Ramadanthi, G. P. (2008). Degradasi Biowaste Fasa Cair dengan Reaktor Batch Anaerobik. Institut Teknologi Bandung, Bandung.

Rees, J. F. (1980). The Fate of Carbon Compounds in The Landfill Disposal of Organic Matter.

Tchobanoglous, G., H.Theissen, S.A Vigil. (1993). Integrated Solid Waste Management. USA: McGraw Hill.

Standar Nasional Indonesia 03-1971-1990 tentang Metode Pengujian Kadar Air Agregat.

Standar Nasional Indonesia 06-2422-1991 tentang Pengujian Keasaman dalam Air dengan Titrimetrik.

Standar Nasional Indonesia 19-3964-1995 tentang Metode Pengambilan dan Pengukuran Contoh Timbulan dan Komposisi Sampah Perkotaan.

Standar Nasional Indonesia 2801:2010 tentang Pupuk Urea. 